\title{
Statistical study concerning the orthodontists' perception of the conventional and self-ligating bracket systems
}

\author{
Claudiu Vartolomei', Dan Serbanoiu', Maria Damasaru' ${ }^{1}$ Dorin Cocos ${ }^{1}$, \\ Dan-Gheorghe Boariu², Mariana Pacurar ${ }^{3}$, Maria Cristina Figueiredo Pollmann ${ }^{4}$ \\ 1"G.E Palade" UMFST, Tg. Mures, Romania \\ ${ }^{2}$ Dent Estet Clinic, Sibiu, Romania \\ ${ }^{3}$ Orthodontics, "G.E Palade" UMFST, Tg. Mures, Romania \\ ${ }^{4}$ Orthodontic Department, Porto University, Portugal
}

\begin{abstract}
Objective. To compare the conventional and self-ligating brackets systems from the point of view of the clinician. Material and methods. A survey was delivered to orthodontists from the international community $(n=130)$ in order to evaluate and compare different proprieties of the two systems.

Results. Conventional brackets are preferred when it comes to bonding technique, final results from an aesthetic and functional point of view and quality-price ratio, while self-ligating brackets are elected for improved patient hygiene, less chairside time and reduced friction and global treatment time.

Conclusions. Orthodontists currently use both systems in their practice and each of them has certain features which makes them superior in comparison to the other.
\end{abstract}

Keywords: orthodontists, perception, conventional brackets, self-ligating brackets

\section{INTRODUCTION}

Conventional and self-ligating braces are widely used in the current orthodontics practice. Popularity of the last has grown during the past decade and many of the clinicians use both or have settled for one of the systems [1]. Manufacturers claim several advantages of the self-ligating braces over the conventional ones, the most important trait being the reduced friction between archwires and the bracket slot, thus improving treatment mechanics [2]. Other more effective characteristics include improved patient comfort and oral hygiene, less activation time and reduced global treatment time [3].

The literature provides contradictory information regarding these aspects with research stating that shorter chair time and less incisor proclination are the only significant advantages of self-ligating systems over conventional systems or that time to initial alignment is actually shorter for the conventional brackets than for either the active or passive self-ligating brackets $[4,5]$.

\section{AIM}

The purpose of this study is to assess the orthodontist's point of view on the self-ligating and conventional bracket systems, regarding clinical experience.

\section{MATERIAL AND METHOD}

A de novo conceived questionary was elaborated by means of Google Forms and it comprised 23 questions as follows: one single-answer question 
regarding the preference for one of the systems, 20 single-answer questions containing a 1 to 5 scale with the purpose of appreciating different proprieties and aspects of the bracket systems and two descriptive questions concerning the uses system (Figure 1,2).

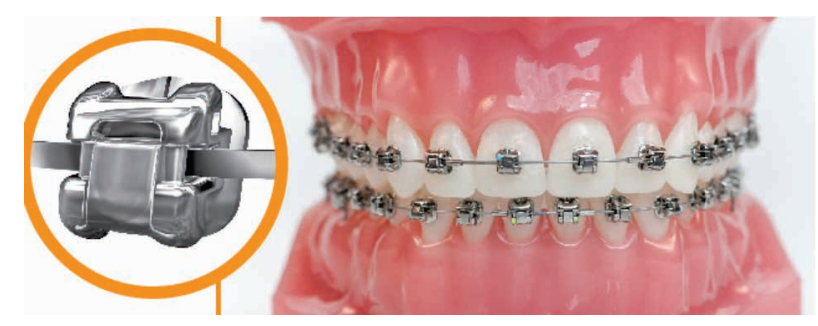

FIGURE 1. Autoligaturant system

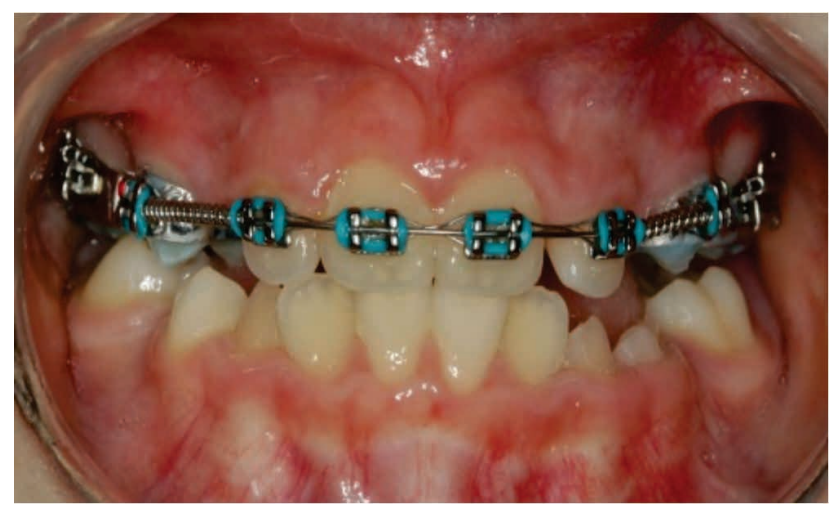

FIGURE 2. Conventional system (elastic ligatures)

For the validation of the questionary, Cronbach's Alpha's coefficient was calculated. The statistical analysis included descriptive statistics (frequency, percent, mean, median, standard deviation) and inferential statistics elements. Shapiro-Wilk test was applied in order to determine the distribution of the analysed data series. For median comparison, Mann Whitney test was used. The chosen $\mathrm{p}$ threshold significance was 0.05 . The statistical analysis was performed in demo GraphPad Prism. 130 answers were recorded.

TABLE 1. Case processing summary

\begin{tabular}{|l|l|r|r|}
\hline \multicolumn{2}{|c|}{} & $\mathbf{N}$ & \multicolumn{2}{|c|}{ \% } \\
\hline \multirow{3}{*}{ Cases } & Valid & 125 & 96.2 \\
\cline { 2 - 4 } & Excluded $^{a}$ & 5 & 3.8 \\
\cline { 2 - 4 } & Total & 130 & 100.0 \\
\hline
\end{tabular}

a. Listwise deletion based on all variables in theprocedure.

TABLE 2. Reliability statistics

\begin{tabular}{|l|l|}
\hline Cronbach's Alpha & N of items \\
\hline .857 & 20 \\
\hline
\end{tabular}

The value of Cronbach's Alpha means that the questions included in the enquiry show proper consistency.

\section{RESULTS}

Question 1: Do you use or have used in your current orthodontic practice?

a. Only the conventional bracket system (MBT, Roth, Alexander etc.)

b. Only the self-ligating bracket system (Damon, H4, PDS etc.)

c. Both systems

TABLE 3. Answers at the question 1

\begin{tabular}{|l|r|r|}
\hline $\begin{array}{l}\text { Do you use or have used in your } \\
\text { current orthodontic practice? }\end{array}$ & Frequency & Percent \\
\hline Both systems & 107 & $82.95 \%$ \\
\hline $\begin{array}{l}\text { Only the conventional bracket system } \\
\text { (MBT, Roth, Alexander, etc.) }\end{array}$ & 15 & $11.63 \%$ \\
\hline $\begin{array}{l}\text { Only the self-ligating bracket system } \\
\text { (Damon, H4, PDS, etc.) }\end{array}$ & 7 & $5.43 \%$ \\
\hline Total & 129 & $100.00 \%$ \\
\hline
\end{tabular}

As noticed in table $1,83 \%$ of the questioned orthodontist use both system in their praxis.

The following questions have been grouped two by two, alternatively approaching the conventional and the self-ligating systems. Each of them is given a score from 1 to 5 ( 1 represents the minimum/the worst/the least effective and 5 the maximum/the best/the most effective) for the following physical and chemical proprieties and perceptional/clinical aspects:

- Bonding technique

- Enamel adhesion

- Patient comfort

- Oral hygiene

- Activation time

- Tooth movement - friction

- Global treatment time

- Debonding technique

- Final aesthetic and functional result

- Quality-price ratio

Questions 2 and 3: On a scale from 1 to 5, how accesible do you find the bonding technique in the conventional system and the self-ligating system? 
TABLE 4. Answers at the questions 2 and 3

\begin{tabular}{|l|r|r|}
\hline Bonding technique & $\begin{array}{l}\text { Conventional } \\
\text { system }\end{array}$ & $\begin{array}{l}\text { Self-ligating } \\
\text { system }\end{array}$ \\
\hline Score 1 & $1(0.78 \%)$ & $5(3.94 \%)$ \\
\hline Score 2 & $4(3.10 \%)$ & $8(6.30 \%)$ \\
\hline Score 3 & $9(6.98 \%)$ & $36(28.35 \%)$ \\
\hline Score 4 & $50(38.76 \%)$ & $37(29.13 \%)$ \\
\hline Score 5 & $65(50.39 \%)$ & $41(32.28 \%)$ \\
\hline Total & 129 & 127 \\
\hline
\end{tabular}

TABLE 5. The statistical analysis for bonding technique

\begin{tabular}{|l|r|r|}
\hline Bonding technique & $\begin{array}{l}\text { Conventional } \\
\text { system }\end{array}$ & $\begin{array}{l}\text { Self-ligating } \\
\text { system }\end{array}$ \\
\hline Number of values & 129 & 127 \\
\hline Minimum & 1.000 & 1.000 \\
\hline Median & 5.000 & 4.000 \\
\hline Maximum & 5.000 & 5.000 \\
\hline Mean & 4.349 & 3.795 \\
\hline Std. deviation & 0.8067 & 1.086 \\
\hline
\end{tabular}

Concerning the bonding technique, in the case of the conventional system, the mean of the scores was $4.349 \pm 0.8067$ (median $=5.000)$ whilst in the case of the self-ligating system, it was $3.795 \pm 1.086$ (median $=4.000)$. The Mann Whitney test, $\mathrm{p}<0.0001(\mathrm{p}<0.05)$ indicates a statistically significant difference between the medians of the two scores.

TABLE 6. The statistical analysis for table 5

\begin{tabular}{|l|r|}
\hline Table analyzed & Data 1 \\
\hline Column A & Conventional system \\
\hline vs. & vs. \\
\hline Column B & Self-ligating system \\
\hline Mann Whitney test & P $<0.0001$ \\
\hline P value & $* * *$ \\
\hline Exact or approximate P value? & Gaussian Approximation \\
\hline P value summary & Yes \\
\hline $\begin{array}{l}\text { Are medians signif. different? } \\
(P<0.05)\end{array}$ & \\
\hline
\end{tabular}

Questions 4 and 5: On a scale from 1 to 5, how effective do you find the bracket to enamel adhesion in conventional systems and in self-ligating systems?

TABLE 7. Answers at the questions 4 and 5

\begin{tabular}{|l|r|r|}
\hline Enamel adhesion & \multicolumn{1}{|l|}{$\begin{array}{l}\text { Conventional } \\
\text { system }\end{array}$} & Self-ligating system \\
\hline Score 1 & $0(0.00 \%)$ & $1(0.79 \%)$ \\
\hline Score 2 & $2(1.55 \%)$ & $3(2.36 \%)$ \\
\hline Score 3 & $17(13.18 \%)$ & $15(11.81 \%)$ \\
\hline Score 4 & $55(42.64 \%)$ & $46(36.22 \%)$ \\
\hline Score 5 & $55(42.64 \%)$ & $62(48.82 \%)$ \\
\hline Total & 129 & 127 \\
\hline
\end{tabular}

TABLE 8. The statistical analysis for enamel adhesion

\begin{tabular}{|l|r|r|}
\hline Enamel adhesion & $\begin{array}{l}\text { Conventional } \\
\text { system }\end{array}$ & Self-ligating system \\
\hline Number of values & 129 & 127 \\
\hline Minimum & 2.000 & 1.000 \\
\hline Median & 4.000 & 4.000 \\
\hline Maximum & 5.000 & 5.000 \\
\hline Mean & 4.264 & 4.299 \\
\hline Std. deviation & 0.7450 & 0.8292 \\
\hline
\end{tabular}

Regarding enamel adhesion, in the conventional system, the mean of the scores was $4.264 \pm 0.7450$ (median $=4.000)$ while in the self-ligating system, the mean was $4.299 \pm 0.8292$ (median $=4.000)$. The Mann Whitney test, $p=0.4610(p>0.05)$ does not indicate any statistically significant difference between the medians of the given scores.

TABLE 9. The statistical analysis for table 8

\begin{tabular}{|l|r|}
\hline Table analyzed & Data 2 \\
\hline Column A & $\begin{array}{r}\text { Conventional } \\
\text { system }\end{array}$ \\
\hline vs. & vs. \\
\hline Column B & Self-ligating system \\
\hline Mann Whitney test & 0.4610 \\
\hline P value & $\begin{array}{r}\text { Gaussian } \\
\text { approximation }\end{array}$ \\
\hline Exact or approximate P value? & ns \\
\hline P value summary & No \\
\hline Are medians signif. different? $(P<0.05)$ &
\end{tabular}

Questions 6 and 7: On a scale from 1 to 5, how comfortable do you believe the conventional and the self-ligating brackets are for the patient? (or have been told by the patient)

TABLE 10. Answers at questions 6 and 7

\begin{tabular}{|l|r|r|}
\hline Patient comfort & Conventional system & Self-ligating system \\
\hline Score 1 & $2(1.55 \%)$ & $4(3.15 \%)$ \\
\hline Score 2 & $8(6.20 \%)$ & $3(2.36 \%)$ \\
\hline Score 3 & $44(34.11 \%)$ & $25(19.69 \%)$ \\
\hline Score 4 & $54(41.86 \%)$ & $55(43.31 \%)$ \\
\hline Score 5 & $21(16.28 \%)$ & $40(31.50 \%)$ \\
\hline Total & 129 & 127 \\
\hline
\end{tabular}

TABLE 11. Statistical analysis for patient comfort

\begin{tabular}{|l|r|r|}
\hline \multicolumn{1}{|c|}{ Patient comfort } & \multicolumn{1}{|c|}{$\begin{array}{c}\text { Conventional } \\
\text { system }\end{array}$} & Self-ligating system \\
\hline Number of values & 129 & 127 \\
\hline Minimum & 1.000 & 1.000 \\
\hline Median & 4.000 & 4.000 \\
\hline Maximum & 5.000 & 5.000 \\
\hline Mean & 3.651 & 3.976 \\
\hline Std. deviation & 0.8808 & 0.9467 \\
\hline
\end{tabular}


When it comes to patient comfort, in the conventional system, the mean was $3.651 \pm 0.8808$ (median $=4.000)$ and in the self-ligating system, the mean was 3.976 \pm 0.9467 (median $=4.000)$. The applied Mann Whitney test, $\mathrm{p}=0.0011(\mathrm{p}<0.05)$ indicates the fact that there exists a statistically significant difference between the medians of the scores for the two systems.

TABLE 12. Statistical analysis for table 11

\begin{tabular}{|l|r|}
\hline Table analyzed & Data 3 \\
\hline Column A & Conventional system \\
\hline Column B & Self-ligating system \\
\hline Mann Whitney test & 0.0011 \\
\hline P value & $\begin{array}{r}\text { Gaussian } \\
\text { approximation }\end{array}$ \\
\hline Exact or approximate P value? & $* *$ \\
\hline P value summary & Yes \\
\hline $\begin{array}{l}\text { Are medians signif. different? } \\
(P<0.05)\end{array}$ & \\
\hline
\end{tabular}

Questions 8 and 9: On a scale from 1 to 5, how do you assess the patients' oral hygiene in the conventional and self-ligating braces systems?

TABLE 13. Answers at questions 8 and 9

\begin{tabular}{|l|r|r|}
\hline Patient oral hygiene & \multicolumn{1}{|l|}{$\begin{array}{l}\text { Conventional } \\
\text { system }\end{array}$} & $\begin{array}{l}\text { Self-ligating } \\
\text { system }\end{array}$ \\
\hline Score 1 & $0(0.00 \%)$ & $0(0.00 \%)$ \\
\hline Score 2 & $18(13.95 \%)$ & $9(7.14 \%)$ \\
\hline Score 3 & $67(51.94 \%)$ & $37(29.37 \%)$ \\
\hline Score 4 & $35(27.13 \%)$ & $66(52.38 \%)$ \\
\hline Score 5 & $9(6.98 \%)$ & $14(11.11 \%)$ \\
\hline Total & 129 & 126 \\
\hline
\end{tabular}

TABLE 14. Statistical analysis for patient oral hygiene

\begin{tabular}{|l|r|r|}
\hline Patient oral hygiene & \multicolumn{1}{|c|}{$\begin{array}{c}\text { Conventional } \\
\text { system }\end{array}$} & \multicolumn{1}{|c|}{$\begin{array}{c}\text { Self-ligating } \\
\text { system }\end{array}$} \\
\hline Number of values & 129 & 126 \\
\hline Minimum & 2.000 & 2.000 \\
\hline Median & 3.000 & 4.000 \\
\hline Maximum & 5.000 & 5.000 \\
\hline Mean & 3.271 & 3.675 \\
\hline Std. deviation & 0.7881 & 0.7676 \\
\hline
\end{tabular}

When talking about the patient's oral hygiene, in the conventional system, the mean of the scores was $3.271 \pm 0.7881$ (median $=3.000$ ) and in the self-ligating system, it was $3.675 \pm 0.7676$ (median $=4.000)$. The Mann Whitney test, $\mathrm{p}<0.0001$ $(\mathrm{p}<0.05)$, shows a statistically significant difference between the medians of the two scores.
TABLE 15. Statistical analysis for table 14

\begin{tabular}{|l|r|}
\hline Table analyzed & Data 4 \\
\hline Column A & Conventional system \\
\hline vs. & velf-ligating system \\
\hline Column B & P<0.0001 \\
\hline Mann Whitney test & $\begin{array}{r}\text { Gaussian } \\
\text { approximation }\end{array}$ \\
\hline P value & $* * *$ \\
\hline Exact or approximate P value? & Yes \\
\hline P value summary & $\begin{array}{l}\text { Are medians signif. different? } \\
(P<0.05)\end{array}$ \\
\hline
\end{tabular}

Questions 10 and 11: On a scale from 1 to 5, how do you assess the activation time in conventional braces? What about in self-ligating braces?

TABLE 16. Answers at questions 10 and 11

\begin{tabular}{|l|r|r|}
\hline Activation time & Conventional system & Self-ligating system \\
\hline Score 1 & $3(2.33 \%)$ & $3(2.36 \%)$ \\
\hline Score 2 & $14(10.85 \%)$ & $7(5.51 \%)$ \\
\hline Score 3 & $44(34.11 \%)$ & $15(11.81 \%)$ \\
\hline Score 4 & $46(35.66 \%)$ & $53(41.73 \%)$ \\
\hline Score 5 & $22(17.05 \%)$ & $49(38.58 \%)$ \\
\hline Total & 129 & 127 \\
\hline
\end{tabular}

TABLE 17. Statistical analysis for activation time

\begin{tabular}{|l|r|r|}
\hline Activation time & Conventional system & Self-ligating system \\
\hline Number of values & 129 & 127 \\
\hline Minimum & 1.000 & 1.000 \\
\hline Median & 4.000 & 4.000 \\
\hline Maximum & 5.000 & 5.000 \\
\hline Mean & 3.543 & 4.087 \\
\hline Std. deviation & 0.9763 & 0.9679 \\
\hline
\end{tabular}

When discussing about the activation time, in the conventional system, the mean of the given scores was $3.543 \pm 0.9763$ (median $=4.000$ ) while in the self-ligating system, the mean was $4.087 \pm 0.9679$ (median $=4.000)$. The Mann Whitney test, $\mathrm{p}<0.0001(\mathrm{p}<0.05)$ indicates a statistically significant difference between the medians of the scores for the systems.

TABLE 18. Statistical analysis for table 17

\begin{tabular}{|l|r|}
\hline Table analyzed & Data 5 \\
\hline Column A & Coventional system \\
\hline vs. & vs. \\
\hline Column B & Self-ligating system \\
\hline Mann Whitney test & P $<0.0001$ \\
\hline P value & Gaussian approximation \\
\hline Exact or approximate P value? & Yes \\
\hline P value summary & \\
\hline $\begin{array}{l}\text { Are medians signif. different? } \\
(\mathrm{P}<0.05)\end{array}$ & \\
\hline
\end{tabular}


Questions 12 and 13: On a scale from 1 to 5, how do you evaluate the tooth movement (regarding friction) in the conventional bracket system and in the self-ligating one?

TABLE 19. Answers at questions 12 and 13

\begin{tabular}{|l|r|r|}
\hline Tooth movement - friction & $\begin{array}{l}\text { Conventional } \\
\text { system }\end{array}$ & $\begin{array}{l}\text { Self-ligating } \\
\text { system }\end{array}$ \\
\hline Score 1 & $0(0.00 \%)$ & $0(0.00 \%)$ \\
\hline Score 2 & $8(6.25 \%)$ & $5(3.94 \%)$ \\
\hline Score 3 & $49(38.28 \%)$ & $14(11.02 \%)$ \\
\hline Score 4 & $51(39.84 \%)$ & $61(48.03 \%)$ \\
\hline Score 5 & $20(15.63 \%)$ & $47(37.01 \%)$ \\
\hline Total & 128 & 127 \\
\hline
\end{tabular}

TABLE 20. Statistical analysis for tooth movementfriction

\begin{tabular}{|l|r|r|}
\hline Tooth movement - friction & $\begin{array}{l}\text { Conventional } \\
\text { system }\end{array}$ & $\begin{array}{l}\text { Self-ligating } \\
\text { system }\end{array}$ \\
\hline Number of values & 128 & 127 \\
\hline Minimum & 2.000 & 2.000 \\
\hline Median & 4.000 & 4.000 \\
\hline Maximum & 5.000 & 5.000 \\
\hline Mean & 3.648 & 4.181 \\
\hline Std. deviation & 0.8190 & 0.7809 \\
\hline
\end{tabular}

Concerning the tooth movement in relation with friction, in the conventional system, the mean of the scores was $3.648 \pm 0.8190$ (median $=4.000)$, whilst in the self-ligating system, it was $4.181 \pm 0.7809$ (median $=4.000)$. The Mann Whitney test, $\mathrm{p}<0.0001(\mathrm{p}<0.05)$ indicates a statistically significant difference between the two medians of the scores given to the two bracket systems.

TABLE 21. Statistical analysis for table 20

\begin{tabular}{|l|r|}
\hline Table analyzed & Data 6 \\
\hline Column A & Conventional system \\
\hline vs. & vs. \\
\hline Column B & Self-ligating system \\
\hline Mann Whitney test & $P<0.0001$ \\
\hline P value & $* * *$ \\
\hline Exact or approximate P value? & Gaussian approximation \\
\hline P value summary & Yes \\
\hline $\begin{array}{l}\text { Are medians signif. different? } \\
(P<0.05)\end{array}$ & \\
\hline
\end{tabular}

Questions 14 and 15: On a scale from 1 to 5, how would you assess the global treatment time in conventional brackets and in self-ligating brackets?
TABLE 22. Answers at questions 14 and 15

\begin{tabular}{|l|r|r|}
\hline Global treatment time & $\begin{array}{l}\text { Conventional } \\
\text { system }\end{array}$ & Self-ligating system \\
\hline Score 1 & $0(0.00 \%)$ & $1(0.79 \%)$ \\
\hline Score 2 & $3(2.33 \%)$ & $8(6.30 \%)$ \\
\hline Score 3 & $45(34.88 \%)$ & $18(14.17 \%)$ \\
\hline Score 4 & $51(39.53 \%)$ & $59(46.46 \%)$ \\
\hline Score 5 & $30(23.26 \%)$ & $41(32.28 \%)$ \\
\hline Total & 129 & 127 \\
\hline
\end{tabular}

TABLE 23. Statistical analysis for global treatment time

\begin{tabular}{|l|r|r|}
\hline \multicolumn{1}{|c|}{ Global treatment time } & \multicolumn{1}{c|}{$\begin{array}{c}\text { Conventional } \\
\text { system }\end{array}$} & $\begin{array}{c}\text { Self-ligating } \\
\text { system }\end{array}$ \\
\hline Number of values & 129 & 127 \\
\hline Minimum & 2.000 & 1.000 \\
\hline Median & 4.000 & 4.000 \\
\hline Maximum & 5.000 & 5.000 \\
\hline Mean & 3.837 & 4.031 \\
\hline Std. deviation & 0.8081 & 0.8903 \\
\hline
\end{tabular}

Regarding global treatment time, in the conventional system, the mean of the scores was $3.837 \pm 0.8081$ (median $=4.000)$ and in the self-ligating system, the mean was $4.031 \pm 0.8903$ (medi$\mathrm{an}=4.000$ ). The Mann Whitney test, $\mathrm{p}=0.0206$ ( $\mathrm{p}$ $<0.05$ ) shows a statistically significant difference between the median of the scores accorded to the two systems.

TABLE 24. Statistical analysis for table 23

\begin{tabular}{|l|r|}
\hline Table analyzed & Data 7 \\
\hline Column A & Conventional system \\
\hline vs. & vs. \\
\hline Column B & Self-ligating system \\
\hline P value & 0.0206 \\
\hline Exact or approximate P value? & Gaussian approximation \\
\hline P value summary & Yes \\
\hline $\begin{array}{l}\text { Are medians signif. different? } \\
(P<0.05)\end{array}$ & \\
\hline
\end{tabular}

Questions 16 and 17: On a scale from 1 to 5, how would you evaluate the debonding technique (concerning easiness) in conventional systems and in self-ligating systems?

TABLE 25. Answers at questions 16 and 17

\begin{tabular}{|l|r|r|}
\hline Debonding technique & $\begin{array}{l}\text { Conventional } \\
\text { system }\end{array}$ & Self-ligating system \\
\hline Score 1 & $1(0.78 \%)$ & $1(0.79 \%)$ \\
\hline Score 2 & $3(2.33 \%)$ & $4(3.17 \%)$ \\
\hline Score 3 & $18(13.95 \%)$ & $21(16.67 \%)$ \\
\hline Score 4 & $54(41.86 \%)$ & $59(46.83 \%)$ \\
\hline Score 5 & $53(41.09 \%)$ & $41(32.54 \%)$ \\
\hline Total & 129 & 126 \\
\hline
\end{tabular}


TABLE 26. Statistical analysis for debonding technique

\begin{tabular}{|c|c|c|}
\hline Debonding technique & $\begin{array}{l}\text { Conventional } \\
\text { system }\end{array}$ & $\begin{array}{l}\begin{array}{l}\text { Self-ligating } \\
\text { system }\end{array} \\
\end{array}$ \\
\hline Number of values & 129 & 126 \\
\hline Minimum & 1.000 & 1.000 \\
\hline Median & 4.000 & 4.000 \\
\hline Maximum & 5.000 & 5.000 \\
\hline Mean & 4.202 & 4.071 \\
\hline Std. deviation & 0.8233 & 0.8312 \\
\hline
\end{tabular}

In the case of bracket debonding technique, in the conventional system, the mean of the given scores was $4.202 \pm 0.8233$ (median $=4.000$ ) whilst in the self-ligating system, the mean was $4.071 \pm 0.8312$ (median $=4.000)$. The Mann Whitney test, $\mathrm{p}=0.1697(\mathrm{p}>0.05)$ indicates no statistically significant difference between the medians of the two scores.

TABLE 27. Statistical analysis for table 26

\begin{tabular}{|l|r|}
\hline Table analyzed & Data 8 \\
\hline Column A & Conventional system \\
\hline Vs. & vs. \\
\hline Column B & Self-ligating system \\
\hline Mann Whitney test & $\begin{array}{r}0.1697 \\
\hline \text { P value }\end{array}$ \\
\hline Exact or approximate P value? & $\begin{array}{r}\text { Gaussian } \\
\text { approximation }\end{array}$ \\
\hline P value summary & No \\
\hline $\begin{array}{l}\text { Are medians signif. different? } \\
(P<0.05)\end{array}$ & \\
\hline
\end{tabular}

Questions 18 and 19: On a scale from 1 to 5, how do you assess the final results, aesthetically and functionally, in the conventional and self-ligating bracket systems?

TABLE 28. Answers at questions 18 and 19

\begin{tabular}{|l|r|r|}
\hline $\begin{array}{l}\text { Final aesthetic and } \\
\text { functional result }\end{array}$ & $\begin{array}{l}\text { Conventional } \\
\text { system }\end{array}$ & $\begin{array}{l}\text { Self-ligating } \\
\text { system }\end{array}$ \\
\hline Score 1 & $1(0.78 \%)$ & $0(0.00 \%)$ \\
\hline Score 2 & $2(1.55 \%)$ & $7(5.51 \%)$ \\
\hline Score 3 & $11(8.53 \%)$ & $22(17.32 \%)$ \\
\hline Score 4 & $56(43.41 \%)$ & $57(44.88 \%)$ \\
\hline Score 5 & $59(45.74 \%)$ & $41(32.28 \%)$ \\
\hline Total & 129 & 127 \\
\hline
\end{tabular}

TABLE 29. Statistical analysis for final aesthetic and functional result

\begin{tabular}{|l|r|r|}
\hline $\begin{array}{l}\text { Final aesthetic and } \\
\text { functional result }\end{array}$ & $\begin{array}{l}\text { Conventional } \\
\text { system }\end{array}$ & $\begin{array}{l}\text { Self-ligating } \\
\text { system }\end{array}$ \\
\hline Number of values & 129 & 127 \\
\hline Minimum & 1.000 & 2.000 \\
\hline Median & 4.000 & 4.000 \\
\hline Maximum & 5.000 & 5.000 \\
\hline Mean & 4.318 & 4.039 \\
\hline
\end{tabular}

Regarding the final aesthetic and functional result, in the conventional system, the mean of the scores was $4.318 \pm 0.7602$ (median $=4.000)$ while in the self-ligating system, the mean was $4.039 \pm 0.8489$ (median $=4.000)$. The Mann Whitney test, $p=0.0056(p<0.05)$ indicates a statistically significant difference between the medians of the scores given to the two systems.

TABLE 30. Statistical analysis for table 29

\begin{tabular}{|l|r|}
\hline Table analyzed & Data 9 \\
\hline Column A & Conventional system \\
\hline vs. & vs. \\
\hline Column B & Self-ligating system \\
\hline Mann Whitney test & 0.0056 \\
\hline P value & $\begin{array}{r}\text { Gaussian } \\
\text { approximation }\end{array}$ \\
\hline Exact or approximate P value? & $* *$ \\
\hline P value summary & Yes \\
\hline Are medians signif. different? $(P<0.05)$ & \\
\hline
\end{tabular}

Questions 20 and 21: On a scale from 1 to 5, how would you rate the prices of conventional brackets, taking into consideration the quality-price ratio? What about the prices of the self-ligating system?

TABLE 31. Answers at questions 20 and 21

\begin{tabular}{|c|c|c|}
\hline Quality-price ratio & $\begin{array}{l}\text { Conventional } \\
\text { system }\end{array}$ & $\begin{array}{l}\text { Self-ligating } \\
\text { system }\end{array}$ \\
\hline Score 1 & $1(0.78 \%)$ & $12(9.45 \%)$ \\
\hline Score 2 & $2(1.55 \%)$ & $27(21.26 \%)$ \\
\hline Score 3 & $16(12.40 \%)$ & $45(35.43 \%)$ \\
\hline Score 4 & $42(32.56 \%)$ & $29(22.83 \%)$ \\
\hline Score 5 & 68 (52.71\%) & $14(11.02 \%)$ \\
\hline Total & 129 & 127 \\
\hline
\end{tabular}

TABLE 32. Statistical analysis for quality-price ratio

\begin{tabular}{|l|r|r|}
\hline Quality-price ratio & $\begin{array}{l}\text { Conventional } \\
\text { system }\end{array}$ & \multicolumn{2}{|l|}{$\begin{array}{l}\text { Self-ligating } \\
\text { system }\end{array}$} \\
\hline Number of values & 129 & 127 \\
\hline & & \\
\hline Minimum & 1.000 & 1.000 \\
\hline Median & 5.000 & 3.000 \\
\hline Maximum & 5.000 & 5.000 \\
\hline Mean & 4.349 & 3.047 \\
\hline Std. deviation & 0.8163 & 1.126 \\
\hline
\end{tabular}

Concerning the quality-price ratio, in the conventional system, the mean of the scores was $4.349 \pm 0.8163$ (median $=5.000)$, while in the self-ligating system, it was $3.047 \pm 1.126$ (median $=$ 3.000). The Mann Whitney test, $\mathrm{p}<0.0001$ $(\mathrm{p}<0.05)$, shows us a statistically significant dif- 
ference between the medians of the scores given to the two braces systems.

TABLE 33. Statistical analysis for table 32

\begin{tabular}{|l|r|}
\hline Table analyzed & Data 10 \\
\hline Column A & Conventional system \\
\hline vs. & vs. \\
\hline Column B & Self-ligating system \\
\hline Mann Whitney test & P $<0.0001$ \\
\hline P value & $\begin{array}{r}\text { Gaussian } \\
\text { approximation }\end{array}$ \\
\hline Exact or approximate P value? & $* * *$ \\
\hline P value summary & Yes \\
\hline $\begin{array}{l}\text { Are medians signif. different? } \\
(P<0.05)\end{array}$ & \\
\hline
\end{tabular}

\section{DISCUSSIONS}

Our study revealed that the self-ligating system is preferred when it comes to patient comfort. Lai et al. indicated in their study that there is no evidence that pain intensity differs between conventional brackets and self-ligating brackets [7]. Yang et al. show that self-ligating brackets do not outperform conventional brackets in relieving discomfort or improving oral health [8].

Prettyman et al. conducted a study in which the participating orthodontists reported a perceived clinical difference between self-ligating brackets and conventional brackets with regard to orthodontic treatment. Self-ligating brackets were preferred by orthodontists more often than conventional brackets for the majority of the treatment factors evaluated but their preferrence was influenced by certain factors [2].

Aljabaa et al. determined the orthodontists perception on the two systems and understood that orthodontics prefer the self-ligating braces for initial treatment, less chairside time, oral hygiene and less extractions and conventional braces for cost, space closure and better finishing and detalining [9].

Fleming et al. plead for insufficient quality evidence to support use of self-ligating appliances over conventional appliances [6,10]. Out of 31 comparison randomized controlled and splitmouth trials between self-ligating and conventional systems, only 9 indicated statistically significant differences, thus contradicting most of the claims of the manufacturers [11].

The American Board of Orthodontics criteria indicate that faster orthodontic treatments are better orthodontic treatments. Responses showed that patients undergoing self-ligating treatment perceive their treatment time as being shorter than expected [12]. Orthodontists, as well as their patients, are interested in reducing the global treatment time [13].

Other factors taken into consideration in the scientific literature is external apical root resorption after orthodontic treatment and extraction rate. The two do not differ between the two brackets systems [14].

\section{CONCLUSIONS}

The majority of the orthodontist specialists use both systems in their practice, but conventional bracket systems are more accessible taking into consideration the quality-price ratio. They consider the bonding technique more accessible in the conventional bracket system but enamel adhesion is similar in both systems.

Oral hygiene and patient comfort are superior in patients undergoing treatment with self-ligating brackets. Adjustment appointments takes less time in patients with self-ligating brackets, but there is no difference between the two systems regarding the bonding technique. Tooth movement in relation to friction is considered more effective in self-ligating braces and global treatment time is shorter with this system.

The final results from an aesthetic and functional point of view are better appraised in the conventional bracket system.

Conflict of interest: none declared Financial support: none declared

\section{REFERENCES}

1. Subashree Rathi S, Saravana Pandiyan K, Rengalakshmi S. Popularity and Perceived Efficiency of Self Ligating Brackets among Orthodontists. J Pharm Sci \& Res. 2019;11(12):3782-4.

2. Prettyman $C$, Best AM, Lindauer SJ, Tufekci E. Self-ligating vs. conventional brackets as perceived by orthodontists. The Angle Orthodontist. 2012 Nov;82(6):1060-6.

3. Harradine N. The History and Development of Self-Ligating Brackets. Seminars in Orthodontics. 2008 Mar;14(1):5-18.

4. Chen SS, Greenlee GM, Kim JE, Smith CL, Huang GJ. Systematic review of self-ligating brackets. Am J Orthod Dentofacial Orthop. 2010 Jun;137(6):726.e1-726.e18. 
5. Songra G, Clover M, Atack NE, Ewings P, Sherriff M, Sandy JR, Ireland AJ. Comparative assessment of alignment efficiency and space closure of active and passive self-ligating vs conventional appliances in adolescents: a single-center randomized controlled trial. Am J Orthod Dentofacial Orthop. 2014 May;145(5):569-78.

6. Fleming PS, DiBiase AT, Lee RT. Self-ligating appliances: evolution or revolution? Aust Orthod J. 2008 May;24(1):41-9.

7. Lai TT, Chiou JY, Lai TC, Chen T, Wang HY, Li CH, Chen MH. Perceived pain for orthodontic patients with conventional brackets or self-ligating brackets over 1 month period: A single-center, randomized controlled clinical trial. J Formos Med Assoc. 2020 Jan;119(1 Pt 2):282-289.

8. Yang X, Su N, Shi Z, Xiang Z, He Y, Han X, Bai D. Effects of self-ligating brackets on oral hygiene and discomfort: a systematic review and meta-analysis of randomized controlled clinical trials. Int J Dent Hygiene. 2017 Feb;15(1):16-22.

9. Aljabaa AH. Does the Perception of Self-Ligating Brackets Differ from Conventional Brackets Among Orthodontists? Biosci Biotech Res Comm. 2020 Dec 25;13(4):1805-11.
10. Fleming PS, Johal A. Self-Ligating Brackets in Orthodontics: A Systematic Review. The Angle Orthodontist. 2010 May; 80(3):575-84

11. Wagner D, Lévy-Benichou H, Lefebvre F, Bolender Y. Are selfligating brackets more efficient than conventional brackets? A meta-analysis of randomized controlled and split-mouth trials. Orthod Fr. 2020 Dec 1;91(4):303-321.

12. Eberting JJ, Straja SR, Tuncay OC. Treatment time, outcome, and patient satisfaction comparisons of Damon and conventional brackets. Clin Orthod Res. 2001 Nov;4(4):228-34.

13. Al-Attar AM, Al-Shaham S, Abid M. Perception of Iraqi Orthodontists and Patients toward Accelerated Orthodontics. International Journal of Dentistry. 2021 Apr 29;2021:1-7.

14. Jacobs C, Gebhardt PF, Jacobs V, Hechtner M, Meila D, Wehrbein $\mathrm{H}$. Root resorption, treatment time and extraction rate during orthodontic treatment with self-ligating and conventional brackets. Head Face Med. 2014 Dec;10(1):2. 